\title{
STAN ZAGROŻENIA. BEZPIECZEŃSTWO WEWNĘTRZNE II RZECZYPOSPOLITEJ
}

\section{Piotr Cichoracki}

http://orcid.org/0000-0003-2523-2679

Uniwersytet Wrocławski

\begin{abstract}
STATE OF DANGER: INTERNAL SECURITY OF THE SECOND POLISH REPUBLIC
\end{abstract}

The paper deals concisely with issues of the internal security in interwar Poland, especially those related to the political determinants. It contains a discussion of the chronology of the transformations that affected the state of security in the years 1918-1939. In the chronological overview of the changes, several sections can be distinguished: 1) the first months of the formation of the state when the public sentiments were also shaped by the extreme emotions being the effect of the end of the war and by the revolutionary movements in the neighbouring territories; 2) the culmination of the Polish-Bolshevik War in the summer of 1920 when the Soviet Army invaded the territory of Poland under the pretence of social revolution; 3) the relatively peaceful 1920s; 4) the Great Depression (in Poland 1930-1935) with a rapid increase in social unrest; 5) the last four years before the outbreak of WWII, characterised by variable intensity of internal tensions. Of key importance to the internal order was the activity of subversive organisations. The most important ones were the communist movement and the Ukrainian nationalist underground. Both took into account armed fight against the Polish state, either on an ongoing basis or in the future. The state of security was also influenced by legitimate political organisations (socialists, peasants' parties and nationalists) but the threat from them was only of a short-term nature and it was not an immediate effect of the decisions made by leaders of these communities. The state apparatus was forced to struggle against different threats to the internal security. The most severe forms were armed revolts, most of which took place in the early 1920 s in the eastern provinces; some of them were provoked by the Soviet secret services. The whole interwar period was full of radical political demonstrations, protests against unemployment, and different forms of peasants' riots. The administration often proved unable to recognise the threats; however, the authorities never allowed the incidents to escalate into a wave of unrest that would jeopardise the national and social order.

Keywords: subversive social movement, internal security, Second Polish Republic, political conflict.

Słowa kluczowe: ruch wywrotowy, bezpieczeństwo wewnętrzne, II Rzeczpospolita, konflikt polityczny. 
Termin „zagrożenie dla bezpieczeństwa wewnętrznego" może być rozumiany rozmaicie. Syntetyczny charakter niniejszego ujęcia skłania do zawężenia definicji. Będzie więc on tu rozumiany jako zaistniałe bądź potencjalne incydenty zewnętrzne, w których uczestniczące strony stosowały przemoc. Pod uwagę zostaną wzięte zarówno otwarte zajścia masowe, jak i działania terrorystyczne/dywersyjne. W sferze naszych zainteresowań pozostaną tylko polityczne uwarunkowania tak rozumianych zagrożeń ładu wewnętrznego. Nie będzie więc uwzględniona przestępczość kryminalna, w żaden sposób niepowiązana z działalnością legalnych i nielegalnych organizacji politycznych. Należy również zastrzec, że zarówno sfera własnych badań, jak i stan literatury dają większe możliwości odwoływania się do sytuacji w drugiej dekadzie istnienia państwa polskiego.

\section{CHRONOLOGIA}

Chronologię zagadnienia zagrożeń dla bezpieczeństwa wewnętrznego można oprzeć wyjściowo na klasycznej periodyzacji historii II RP. W takim ujęciu należałoby wydzielić okres formowania kształtu terytorialnego państwa (1918-1921), czas demokracji parlamentarnej (1922-1926), pierwsze lata rządów obozu sanacyjnego (1926-1930), wielki kryzys gospodarczy (1930-1935) i ostatnie lata przed wybuchem wojny (1936-1939). W wypadku zagrożeń bezpieczeństwa wewnętrznego podział ten wymaga jednak kilku uszczegółowień.

Dla pierwszego wskazanego podokresu zagrożenie wybuchem radykalizmu społecznego zaistniało silnie w dwóch momentach: w pierwszych tygodniach istnienia państwa polskiego oraz latem 1920 roku. Fatalną okoliczność z punktu widzenia bezpieczeństwa wewnętrznego u progu II RP stanowiły oczywiście przykłady rewolucji i przewrotów społecznych oraz politycznych, do których doszło na niemal wszystkich terytoriach sąsiadujących z odradzającym się państwem polskim. Drugim potencjalnym zagrożeniem była polityczna heterogeniczność, wielość oraz wzajemna niechęć instytucji aspirujących do roli strażnika ładu. Mimo to udało się państwu uniknąc wstrząsów wewnętrznych na poważniejszą skalę. Gwałtownie objawiający się ferment społeczny był na przełomie lat 1918 i 1919 lokalizowany (Zagłębie Dąbrowskie, „republika tarnobrzeska”), niepokoje w wojsku miały postać odosobnionych incydentów (Zamość), a przebieg tak zwanego zamachu Januszajtisa w gruncie rzeczy dowodził dużej dojrzałości elit politycznych ${ }^{1}$.

Wpływ wojny polsko-sowieckiej wydaje się w większym stopniu kwestią dyskusyjną. Po raz pierwszy należy ze względów narodowościowych rozróżnić sytuację na dwóch obszarach, rozgraniczonych umowną linią Bugu. Na wschód od niej w latach 1919-1920 sytuacja była pod względem bezpieczeństwa napięta, co wynikało

${ }^{1}$ Rady delegatów robotniczych $w$ Polsce 1918-1919. Materialy $i$ dokumenty, t. I-II, red. A. Tymieniecka, A. Litwin, Warszawa 1965; I. Pawłows ki, Polityka i działalność wojskowa KPP 1918-1928, Warszawa 1964, s. 126-140. 
przede wszystkim z konfliktów pomiędzy niepolską ludnością wiejską a polskimi instytucjami cywilnymi i wojskowymi ${ }^{2}$. Sytuacja na Lubelszczyźnie i Podlasiu w lipcu i sierpniu 1920 roku, w tym współpraca przedstawicieli miejscowej ludności z armią sowiecką, wskazuje, że również tu istniały duże pokłady społecznego niezadowolenia. Zwraca także uwagę w tym kontekście, że represje zastosowane na wskazanym obszarze przez powracające władze polskie bywały brutalne ${ }^{3}$.

Okres od zakończenia wojny polsko-sowieckiej do zamachu majowego można uznać za czas, kiedy poziom warunkowanego politycznie zagrożenia bezpieczeństwa był na tyle wysoki, że objawiał się nie tak licznymi, ale spektakularnymi incydentami (zwłaszcza w drugiej połowie 1923 r.) ${ }^{4}$. Intensywny konflikt polityczny nałożył się na poważne problemy natury ekonomicznej. W tym okresie szczególnie negatywnie na stanie ładu wewnętrznego odbiło się otoczenie zewnętrzne II RP. Sąsiedztwo sowieckie walnie przyczyniło się do rozwoju działalności zbrojnej w województwach wschodnich, bazującej na wsparciu mniejszości narodowych. Przyniosła ona setki incydentów, wśród nich tak spektakularne, że stawiające w stan alarmu najwyższe władze państwa (Stołpce) $)^{5}$.

Zapewne najbardziej stabilnym okresem z punktu widzenia ładu wewnętrznego była druga połowa lat 20., choć oczywiście wymaga to szczególnego potraktowania zamachu majowego i wyeliminowania go z niniejszych rozważań. Na relatywnie wysoki stopień spokoju społecznego wpływ miała niezła sytuacja gospodarcza, a także proces przebudowy sceny politycznej polegający na redefiniowaniu jej podziału na obóz prorządowy - opozycja. Nie oznacza to, że nie dochodziło do spektakularnych i krwawych przypadków zaburzeń społecznych. Symptomatyczna wydaje się tu jednak sytuacja po rozwiązaniu w styczniu 1927 roku radykalnie lewicowej, infiltrowanej przez komunistów Białoruskiej Włościańsko-Robotniczej Hromady. Organizacja notowała gwałtowny wzrost liczby członków jesienią 1926 roku i na pewno dawała wyraz bardzo niechętnym nastrojom w stosunku do państwa polskiego, jakie panowały na prawosławnej wsi województw północno-wschodnich. Mimo to jej likwidacja przyniosła zaledwie jeden poważniejszy incydent w Kosowie (woj. poleskie) ${ }^{6}$.

Okres załamania ekonomicznego pierwszej połowy lat 30. przyniósł falę objawów buntu społecznego, którego apogeum przypadło na lata 1932-1933. W całym okresie lat 1930-1935 miało miejsce niemal tysiąc incydentów o różnej skali związanych ze zbiorowym oporem wobec państwa. Pochłonęły one co najmniej 150 ofiar śmiertelnych. Mimo niemałej liczby i niekiedy dużej intensywności (np. zajścia w Małopolsce Środkowej w czerwcu 1933 r.) można ocenić, że były to odruchy nieskoordynowane, incydentalnie obejmujące obszar do kilku powiatów. Lata 1934-1935 były okresem przejściowym. Z jednej strony odnotowano nagły spadek gwałtownych

2 J. Szczepański, Społeczeństwo Polski w walce z najazdem bolszewickim 1920 r., WarszawaPultusk 2000, s. 149-152.

${ }^{3}$ Idem, Wojna 1920 na Mazowszu i Podlasiu, Warszawa-Pułtusk 1995, s. 209, 238.

${ }^{4}$ Rok 1923 w Krakowie. Rozprawy i studia, red. J. B u s zko, Kraków 1978.

${ }_{5}^{5}$ W. Śle szy ńs ki, Bezpieczeństwo wewnętrzne w polityce państwa polskiego na ziemiach pólnocno-wschodnich II Rzeczypospolitej, Warszawa 2007, s. 293-311.

6 У.А. Пал уян, Беларуская Сялянска-Рабочая Грамада, Мінск 1967, s. 175 i n. 
wystąpień zewnętrznych ludności. Z drugiej strony to właśnie wówczas nasiliły się zjawiska ilustrujące problemy, przed którymi władze II RP staną w ostatnich latach przed wybuchem wojny - zajścia antyżydowskie, casus Wołynia w latach 1934-1935 (bunt chłopski na podłożu radykalnym) ${ }^{7}$.

Drugą połowę lat 30. należy podzielić na dwa podokresy: lata 1936-1937 i 19381939. Pierwszy charakteryzował się bardzo spektakularnymi emanacjami napięć społecznych i politycznych i - być może - należy uznać go pod pewnymi względami za porównywalny z latami 1932-1933. Zwraca jednak uwagę, że w przeciwieństwie do okresu wielkiego kryzysu niepokoje były mniej różnorodne (brak incydentów zbrojnych, marginalizacja form oporu przeciw powinnościom na wsi) ${ }^{8}$. W ostatnim dwuleciu przed wybuchem II wojny światowej nastąpił spadek napięć wyrażanych wystąpieniami zewnętrznymi. Interpretacje tego stanu rzeczy najczęściej zawierają wskazania na wyciszenie sporów wewnętrznych w obliczu zagrożenia wojennego czy likwidację struktur komunistycznych na skutek decyzji sowieckiego kierownictwa ${ }^{9}$. Były to na pewno czynniki istotne, ale ich zaistnienie nie oznaczało likwidacji zagrożeń dla ładu wewnętrznego. Problem ilustruje sytuacja, jaka miała miejsce w województwach wschodnich w okresie kryzysu czechosłowackiego. Możliwość zbrojnego konfliktu polsko-sowieckiego, zarówno w ocenie administracji cywilnej, jak i wojskowej, uczyniła realnym masowe wypowiedzenie posłuszeństwa przez ludność niepolską. Znamienne, że fakt, iż mobilizacja alarmowa, przeprowadzona w marcu 1939 roku głównie na części tegoż obszaru, przebiegła bez problemów, został uznany przez miejscową administrację za swego rodzaju niespodziankę ${ }^{10}$.

\section{ORGANIZACJE WYWROTOWE}

Kluczowe znaczenie dla stanu bezpieczeństwa wewnętrznego miała działalność organizacji wywrotowych, z definicji obliczona na destrukcję bezpieczeństwa wewnętrznego II RP. Przedmiotem refleksji może więc być tu jedynie ewolucja koncepcji sposobu likwidacji istniejącego ładu oraz praktyczny wymiar działalności wywrotowej. Istotne były dwa ośrodki: ruch komunistyczny oraz ukraińscy nacjonaliści spod znaku Ukraińskiej Organizacji Wojskowej/Organizacji Ukraińskich Nacjonalistów.

${ }^{7}$ P. Cich or acki, J. Du frat, J, Mi erzw a, Bunt spoleczny doby wielkiego kryzysu lat 1930-1935. Uwarunkowania, skala, konsekwencje, Kraków 2019.

${ }^{8}$ Wielki Strajk Chtopski w 1937 r. Uwarunkowania i konsekwencje, red. W. Wierzbieniec, Rzeszów 2008; J. Ży n d u 1, Zajścia antyżydowskie w Polsce w latach 1935-1937, Warszawa 1994.

${ }_{9}$ W. Po bóg-Malin ow sk i, Najnowsza historia polityczna Polski. Okres 1914-1939, t. II, Gdańsk 1990, s. 835-836.

${ }^{10} \mathrm{~W}$. Włodarkiewicz, Społeczeństwo województwa poleskiego wobec zagrożenia wojennego $i$ wojny w 1939 roku, „Przegląd Historyczno-Wojskowy” 2009, nr 1, s. 98; AAN, Urząd Wojewódzki Poleski, sygn. 32, k. 15, Sprawozdanie sytuacyjne nr 3 za miesiąc marzec z 14 IV 1939. 
Oceniając koncepcje formułowane w obrębie ruchu komunistycznego, można wskazać na ten moment, kiedy jego kierownictwo zdecydowanie zradykalizowało swoje stanowisko w kwestii metod planowanego przewrotu. Apogeum nastąpiło w latach 1930-1933, kiedy to hasła czynnego oporu wobec instytucji państwa stały się nie tylko kluczowym punktem komunistycznej propagandy, ale i programu. Należy tu wymienić eksponowanie idei „powstania zbrojnego”, rozwijanie koncepcji „samoobrony” jako struktur zdolnych do podjęcia otwartej walki z instytucjami strzegącymi bezpieczeństwa wewnętrznego, wreszcie permanentne wezwania do siłowego sprzeciwiania się powinnościom wobec państwa i próbom zmiany pod jego egidą elementów ustroju rolnego ${ }^{11}$.

Kwestią otwartą pozostają skala i charakter przygotowań organizacyjnych do podjęcia walki z instytucjami państwa. Wydaje się, że nie był to proces zaawansowany, a wystąpienia z użyciem przemocy, które można pośrednio lub bezpośrednio powiązać $\mathrm{z}$ działalnością komunistyczną, $\mathrm{w}$ dużej mierze miały spontaniczny charakter buntu ludności. Cechą szczególną ruchu komunistycznego w II RP było nominalne wyodrębnienie organizacji białoruskiej i ukraińskiej. Mimo wspólnych głównych założeń ideowych i taktycznych można dostrzec pomiędzy nimi pewne różnice dotyczące sposobu destabilizowania bezpieczeństwa państwa polskiego. Zarówno w pierwszej połowie lat 20., jak i w okresie wielkiego kryzysu stanowiska Komunistycznej Partii Zachodniej Białorusi czy Komunistycznej Partii Zachodniej Ukrainy wydają się bardziej radykalne aniżeli artykułowane w obrębie kierownictwa Komunistycznej Partii Robotniczej Polski/Komunistycznej Partii Polski ${ }^{12}$.

Naczelnym założeniem UWO/OUN była walka zbrojna o niezawisłe państwo ukraińskie. Przez cały okres międzywojenny prowadzono szerokie i różnorodne przygotowania do jej wzniecenia, a później zwycięskiego zakończenia. Jeśli chodzi o koncepcje powstańcze czy wizje udziału formacji ukraińskich w konflikcie zbrojnym po stronie któregoś z sąsiadów II RP, należy stwierdzić, że z punktu widzenia władz polskich było to jednak zagrożenie teoretyczne. Praktyczne znaczenie miało natomiast prowadzenie przez UWO/OUN działalności terrorystycznej. Miała ona wiele form (zamachy skierowane przeciw indywidualnym osobom, ekspropriacje, podpalenia) i z różnym nasileniem była prowadzona przez całe dwudziestolecie. $Z$ wyjątkiem pojedynczych incydentów (np. akcja „sypania mogił” w 1934 r.) praktyczna czy propagandowa działalność UWO/OUN nie wywoływała zaburzeń masowych ${ }^{13}$. W sposób zasadniczy odróżniało to konsekwencje funkcjonowania ukraińskiego podziemia od skutków działania jego komunistycznego odpowiednika. Traktując oddzielnie UWO/ OUN i KPP, należy jednak zaznaczyć, że na poziomie terenowym ich wywrotowa propaganda przenikała się. Dotyczyło to wszystkich obszarów, gdzie przeważała

${ }^{11}$ H. Cimek, L. Kieszczyński, Komunistyczna Partia Polski 1918-1938, Warszawa 1984, s. $221 \mathrm{i} \mathrm{n}$.

12 Революиионный путь Компартии Западной Беларуссии, red. А.Н. Мацко, В.Е. Самутин, Минск 1966, s. 208-210.

${ }_{13}$ R. Wy socki, Organizacja Ukrainskich Nacjonalistów w Polsce w latach 1929-1939, Lublin 2003, s. 233-359. 
ludność ukraińska, ale najwyraźniej zjawisko to można zaobserwować na Wołyniu ${ }^{14}$. Wspólną cechą obu struktur była również działalność terrorystyczna o charakterze kontrwywiadowczym, prowadzona przez całe dwudziestolecie.

Rolę w inspiracji niepokojów odegrały służby specjalne sąsiadów II RP. Odnosi się to zwłaszcza do instytucji sowieckich. Charakter zależności od Moskwy ruchu komunistycznego działającego na terenie Polski powoduje, że sam wpływ służb bezpieczeństwa/wywiadu ZSRS na interesującą nas sferę możemy uznać za pewnik. Precyzyjne określenie jego skali i charakteru wciąż jednak pozostaje w sferze przypuszczeń. Nie ulega wątpliwości, że sowiecki wywiad wojskowy był współodpowiedzialny za wystąpienia zbrojne, do których dochodziło na terenie województw wschodnich w pierwszej połowie lat 20. Sprawą otwartą jest natomiast możliwość inspiracji gwałtownych wystąpień w okresie późniejszym. W latach 30. elementem przygotowań sowieckich do wojny było w każdym razie intensywne szkolenie w dziedzinie partyzantki i dywersji, a władze polskie często kojarzyły poszczególne incydenty czy też okoliczności im towarzyszące z aktywnością służb wschodniego sąsiada II RP ${ }^{15}$.

\section{LEGALNE ŻYCIE POLITYCZNE}

Wpływy legalnych organizacji politycznych na stan bezpieczeństwa wynikał z kilku, nie zawsze powiązanych ze sobą czynników. Fundamentalną sprawą było natężenie konfliktu politycznego i aktualny kształt geografii politycznej. Linie podziałów politycznych generujących zagrożenia dla bezpieczeństwa albo biegły wzdłuż linii opozycja - rządzący (państwo), albo wynikały z „bilateralnych” konfliktów pomiędzy poszczególnymi podmiotami życia politycznego. O ile jednak do przewrotu majowego zaistniałe incydenty dadzą się zapewne najczęściej pogrupować według tego klucza, to po 1926 roku podział ten się niejednokrotnie zaciera. W okresie rządów parlamentarnych ,przeciwnikiem” dla występujących na zewnątrz zwolenników opozycji były instytucje państwa: policja, rzadziej wojsko. Od końca lat 20. w celu fizycznego starcia z opozycją rządzący sięgali nie tylko po te oczywiste instrumenty. Narzędziem codziennej walki „na ulicy” stały się prorządowe organizacje społeczne, przede wszystkim Związek Strzelecki. Konsekwencje dla stanu bezpieczeństwa przynosiły rozłamy następujące $\mathrm{w}$ obrębie danej organizacji politycznej. Z punktu widzenia ładu wewnętrznego czołową rolę odgrywały turbulencje, jakie dotknęły w drugiej połowie lat 20. PPS, a więc organizację mocno „ubojowioną”, zarówno ze względu na jej miejski charakter, jak i swego rodzaju tradycję ${ }^{16}$.

${ }^{14}$ B. Hud, Ukraincy i Polacy na Naddnieprzu, Wolyniu i w Galicji Wschodniej w XIX i pierwszej polowie XX wieku, Warszawa 2018, s. 312.

${ }_{15}$ В.С. Ан тонов, В.Н. Карп ов, Мастера разведки и контрразведки, Москва 2009, s. 165.

16 J. Tom ick k, Polska Partia Socjalistyczna 1892-1948, Warszawa 1983, s. 303. 
Można wskazać na kilka specyficznych kategorii zajść, które były lub bywały powiązane z działalnością organizacji politycznych. W latach 30 . terenem ostrych incydentów, inspirowanych przede wszystkim przez środowiska narodowe, były uczelnie wyższe $^{17}$. Kolejną kategorią zajść wartą uwagi są incydenty antyżydowskie. Można założyć, że w okresie międzywojennym było to zjawisko endemiczne, ale swoje apogeum osiągnęło w drugiej połowie lat 30. (ściśle: w latach 1935-1937). Pojawiają się jednak wątpliwości co do ich klasyfikacji, na ile można je wiązać z działalnością polityczną. Inaczej należy bowiem traktować „marsz na Myślenice”, na czele którego stanął prominentny działacz obozu narodowego, inaczej zaś incydenty, które wybuchały spontanicznie i mimo pokaźnych rozmiarów nie były kierowane i organizowane (np. Brześć w 1937 r.). Mianem ,pełzającego” przez całe dwudziestolecie można określić polsko-ukraiński konflikt narodowościowo-polityczny. Jego codzienne formy, konfliktujące lokalne społeczności, zaostrzały się pod wpływem agitacji politycznej zarówno polskich, jak i ukraińskich struktur politycznych. Zjawisko to do 1939 roku widoczne jest raczej w województwach południowo-wschodnich aniżeli na Wołyniu ${ }^{18}$.

\section{PAŃSTWO}

Kolejnym zagadnieniem jest kwestia reakcji państwa na pojawiające się zagrożenia i ewolucja stosowanych przez nie metod utrzymania ładu. Można wskazać trzy tory postępowania. Poczynania „strategiczne”, których celem było wyeliminowanie przyczyn zagrożenia poprzez realizowanie działań politycznych, społecznych i ekonomicznych, zmiany w funkcjonowaniu instytucji odpowiedzialnych za utrzymanie ładu, wreszcie kształtowanie narzędzi, którymi te instytucje dysponowały.

Interpretacja przyczyn zaistniałych bądź potencjalnych niepokojów skłaniała niekiedy do formułowania mniej lub bardziej kompleksowych programów mających na celu pacyfikację nastrojów społecznych. Przykładem takiego pomysłu był program przyspieszenia powojennej rekonstrukcji terenów województw wschodnich, sformułowany w 1924 roku pod wpływem fali wystąpień zbrojnych, które miały tam miejsce $^{19}$. Najczęściej działano jednak metodą mniejszych kroków, czego przykładem jest sekwencja ustaw podatkowych wprowadzanych w pierwszej połowie lat 30 . Zmiany w systemie instytucji obarczonych odpowiedzialnością następowały w obu dekadach. Spektakularną reakcją na zaistniałe zagrożenie było powołanie KOP w 1924 roku. Pod kątem skutecznej reakcji na zaburzenia porządku zwłaszcza w latach 30.

${ }_{17}$ A. Tyszkiewicz, Obóz Wielkiej Polski w Małopolsce 1926-1933, Kraków 2004, s. 378.

${ }^{18}$ O. Linkiewicz, Lokalność $i$ nacjonalizm. Społeczności wiejskie w Galicji Wschodniej $w$ dwudziestoleciu międzywojennym, Warszawa 2018.

19 J. To mas zew sk i, Trzy projekty Władysława Grabskiego, „Kwartalnik Historyczny” 1958, nr 4. 
mocno przekształcono PP. Świadectwem tego jest stopniowa rozbudowa jej zwartych oddziałów dyspozycyjnych, postępująca od 1932 roku do końca dekady ${ }^{20}$.

W sytuacjach kryzysowych, kiedy zagrożenie ładu uznawano za ponadprzeciętnie duże, sięgano po rozwiązania szczególne. Wydaje się, że jeśli chodzi o instytucje znajdujące się pod kontrolą państwa, traktowano je jako czasowe. Tak było na pewno dwukrotnie z wprowadzeniem sądów doraźnych (1922-1927 i 1931-1934), funkcjonujących na części terytorium bądź w całym państwie ${ }^{21}$. Miejsce Odosobnienia w Berezie Kartuskiej utrzymano do 1939 roku, co jednak nie przesądza tego, że z góry uznano je za trwały element systemu represji. Inaczej działo się natomiast najczęściej wtedy, gdy podejmowano decyzje o likwidacji jakiejś struktury politycznej lub społecznej. Po 1926 roku w imię utrzymania ładu wewnętrznego albo rozwiązywano całe organizacje, albo uderzano w ich terenowe struktury. Podobnymi działaniami objęto całe ówczesne opozycyjne spektrum polityczne, choć wydaje się, że więcej wysiłku włożono w unieszkodliwienie radykalnej, komunizującej lewicy. Nawet jednak tu można wskazać wypadek wahań i rewizji raz podjętej decyzji (,„uh”).

Zdawano sobie sprawę $\mathrm{z}$ tego, że wpływ na poziom ładu wewnętrznego ma również zachowanie się funkcjonariuszy państwowych, także bezpośrednio odpowiedzialnych za bezpieczeństwo. W wypadku szeroko rozumianego aparatu urzędniczego starano się go ,wychowywać”, nakazując szacunek i empatię w stosunku do obywatela. Wycinkowa znajomość tego zagadnienia pozwala jednak przypuszczać, że nawet jeśli postępy zostały tu dokonane, to do zakończenia pożądanego procesu zmiany było pod koniec lat 30. jeszcze bardzo daleko. W pierwszej połowie tej dekady można dostrzec pewne symptomy wahania, jeśli chodzi o bezpośrednie stosowanie przemocy w sytuacjach kryzysowych. Poniekąd podobnie jak w wypadku urzędników cywilnych, do 1935 roku dyrektywy MSW nakazywały oględność przy interwencjach i absolutną ostrożność przy użyciu broni. W połowie lat 30 . podejście w tej kwestii osób odpowiedzialnych za utrzymanie ładu się zmieniło. Wypowiedzi na ten temat czy to nowego szefa MSW - Mariana Zyndrama-Kościałkowskiego, czy to świeżo mianowanego komendanta PP Kordiana Zamorskiego nie pozostawiają wątpliwości, że zdecydowano o przyjęciu ostrzejszego kursu'22.

$\mathrm{Na}$ zakończenie wątku reakcji państwa na zagrożenie ładu wewnętrznego należy podnieść kwestie bezprawnych, faktycznie zakonspirowanych działań przedstawicieli aparatu państwowego. Były one podejmowane celem stabilizowania ładu wewnętrznego, a polegały na fizycznej likwidacji osób, które uznano za zagrażające mu. Mimo że siłą rzeczy mamy tu najczęściej do dyspozycji jedynie poszlaki, nie ulega wątpliwości, że środki takie były stosowane.

${ }^{20}$ A. Misiuk, Policja Państwowa 1919-1939. Powstanie, organizacja, kierunki działania, Warszawa 1996, s. 206, 207.

${ }^{21}$ A. Ś mi iłe k, Sądy doraźne w II Rzeczypospolitej, „Czasopismo Prawno-Historyczne” 1984, nr 1.

${ }^{22}$ AAN, KG PP, sygn. 544, k. 96, 103-104, Protokół odprawy komendantów wojewódzkich PP 12 VII 1935. 


\section{WRZESIEŃ}

Otwarta pozostaje odpowiedź na pytanie o bilans zagrożeń w dziedzinie bezpieczeństwa i stopień skuteczności działań państwa zmierzających do ich zażegnania. Wydaje się, że za jedyny realny, choć obciążony wieloma deformacjami test można uznać wrzesień 1939 roku. Na pewno przerwał on wiele procesów, które miałyby wpływ na stan bezpieczeństwa $\mathrm{w}$ realiach pokojowego istnienia państwa. $Z$ drugiej jednak strony przebieg wydarzeń na zapleczu frontu polsko-niemieckiego, a od 17 września - umownie - polsko-sowieckiego pozwala sformułować dwa twierdzenia. Pierwsze dotyczy skuteczności aparatu państwowego w neutralizowaniu zewnętrznych zagrożeń ładu wewnętrznego. Należy ją uznać za wysoką. Do momentu agresji sowieckiej spokój na tyłach WP został zasadniczo utrzymany. Próby jego zaburzenia, jak miało to miejsce w południowych powiatach województw lwowskiego i stanisławowskiego, zostały dość szybko zduszone przy pomocy policji oraz drugo- i trzeciorzutowych oddziałów wojskowych. Nawet dywersja niemiecka, jakkolwiek bardzo uciążliwa, była opanowywana do momentu obecności WP na danym terenie (Bydgoszcz, Górny Śląsk). Agresja sowiecka ukazała jednak w całej pełni, że w odniesieniu do jednej trzeciej obywateli stanowiących mniejszości narodowe trudno mówić o lojalności wobec państwa polskiego. W województwach wschodnich znikała ona często w atmosferze buntu społecznego, a w najlepszym razie niechętnej obojętności przeważającej części mieszkańców. Można więc uznać, że o ile państwo w realiach stabilnego funkcjonowania było w stanie efektywnie kontrolować sferę bezpieczeństwa, o tyle istniejące kluczowe zagrożenia dla niego nie zostały zneutralizowane.

\section{BIBLIOGRAFIA}

\section{Archiwalia}

AAN, Komenda Główna Policji Państwowej, sygn. 544.

AAN, Urząd Wojewódzki Poleski, sygn. 32.

\section{Opracowania}

Cichoracki P., Dufrat J., Mierzwa J., Bunt społeczny doby wielkiego kryzysu lat 1930-1935. Uwarunkowania, skala, konsekwencje, Kraków 2019.

Cimek H., Ki es zc zyńs ki L., Komunistyczna Partia Polski 1918-1938, Warszawa 1984.

Hud B., Ukraincy i Polacy na Naddnieprzu, Wołyniu i w Galicji Wschodniej w XIX i pierwszej połowie XX wieku, Warszawa 2018.

Linkiewicz O., Lokalność i nacjonalizm. Społeczności wiejskie w Galicji Wschodniej $w$ dwudziestoleciu międzywojennym, Warszawa 2018.

Misiuk A., Policja Państwowa 1919-1939. Powstanie, organizacja, kierunki działania, Warszawa 1996. 
Pawłows ki I., Polityka i działalność wojskowa KPP 1918-1928, Warszawa 1964.

Pobóg-Malinowski W., Najnowsza historia polityczna Polski. Okres 1914-1939, t. II, Gdańsk 1990.

Rady delegatów robotniczych w Polsce 1918-1919. Materiaty i dokumenty, t. I-II, red. A. Tymieniecka, A. Litwin, Warszawa 1965.

Rok 1923 w Krakowie. Rozprawy i studia, red. J. Bus zk o, Kraków 1978.

Szczepański J., Społeczeństwo Polski w walce z najazdem bolszewickim 1920 r., Warszawa-Pułtusk 2000.

Szczepański J., Wojna 1920 na Mazowszu i Podlasiu, Warszawa-Pułtusk 1995.

Śleszyński W., Bezpieczeństwo wewnętrzne w polityce państwa polskiego na ziemiach północno-wschodnich II Rzeczypospolitej, Warszawa 2007.

Ś mi ałe k A., Sądy doraźne w II Rzeczypospolitej, „Czasopismo Prawno-Historyczne” 1984, nr 1.

To mas ze w ski J., Trzy projekty Władysława Grabskiego, „Kwartalnik Historyczny” 1958, $\mathrm{nr} 4$.

Tomicki J., Polska Partia Socjalistyczna 1892-1948, Warszawa 1983.

Tys zk i ew ic z A., Obóz Wielkiej Polski w Małopolsce 1926-1933, Kraków 2004.

Wielki Strajk Chłopski w 1937 r. Uwarunkowania i konsekwencje, red. W. Wi er zbi en iec, Rzeszów 2008.

Wło d a r ki e wic z W., Społeczeństwo województwa poleskiego wobec zagrożenia wojennego i wojny w 1939 roku, „Przegląd Historyczno-Wojskowy” 2009, nr 1.

Wy s o c ki R., Organizacja Ukraińskich Nacjonalistów w Polsce w latach 1929-1939, Lublin 2003.

Żyndul J., Zajścia antyżydowskie w Polsce w latach 1935-1937, Warszawa 1994.

Ан тонов В.С., Карпов В.Н., Мастера разведки и контрразведки, Москва 2009.

Палуян У.А., Беларуская Сялянска-Рабочая Грамада, Мінск 1967.

Революционньй путь Компартии Западной Беларуссии, red. А.Н. Мацко,

В.Е. Самут ин, Минск 1966. 